\title{
Marketing Theory: Overview of Ontology, Epistemology, and Axiology Aspects
}

\author{
${ }^{1}$ Tanti Handriana*, ${ }^{2}$ Basu Swastha Dharmmesta \\ ${ }^{1}$ Universitas Airlangga, Indonesia \\ ${ }^{2}$ Universitas Gadjah Mada, Indonesia \\ *handriana_tanti@yahoo.com
}

\begin{abstract}
This article discusses about the marketing theory from the perspective of philosophy of science. The discussion focused on the aspects of the ontology, epistemology, and axiology. From the aspect of the ontology, it seems that the essence of marketing is a useful science and mutually beneficial for both the marketer and the stakeholders, or in other words that marketing knowledge is useful knowledge for the benefit of humankind that can be realized through the exchange process. Side of the ontology covers what the substance of marketing knowledge, the substance of truth and reality that is inherent with marketing. Meanwhile, aspects of epistemology cover a variety of approaches, methods, sources, structure and validation or marketing truth. Finally, axiology fields are related to ethics in marketing and marketing research. Marketing ethics and ethics in marketing research is a crucial matter, including in this case is trust.
\end{abstract}

Keywords: Philosophy of science, marketing theory, ontology, epistemology, axiology

\section{Introduction}

The marketing theory continues to thrive to this day. It is characterized by the rising of various schools of marketing thought and the rising of various isms. The marketing schools of thought comprises commodity school, functional school, institutional school, regional school, functionalist school, managerial school, buyer behavior school, activist school, macro-marketing school, organizational dynamics school, system school, and social exchange school. Shaw (2009) describes why study the history of Marketing Thought? In the academy there are two main reasons for studying any subject-teaching and research. Meanwhile, Hunt (1991) explained various isms of marketing theory, there are empiricism, rationalism, idealism, positivism, realism, relativism, and post-relativism. Marketing is the activity, set of institutions, and processes for creating, communicating, delivering, and exchanging offerings that have value for customers through creating, delivering, and communicating superior customer value (Kotler and Keller, 2012). Some of most basic ideas or convictions about marketing are: (1) whether marketing is more of a science or more of an art is debatable; (2) marketing is both a formative influence and an adaptive aspect of the culture; (3) significant contributions have been made to marketing knowledge by such fields as economics, psychology, sociology, anthropology, cultural ecology, demography, political science, and history; (4) with expected continuing increases in population, productive capacity and living standards, marketing will become increasingly significant; (5) marketing is an integral part of whole productive process, in the sense that it adds values to goods and services through the creation of time, place, possession, and information utilities; and (6) taking a broad view of marketing as a social process does not preclude functional specialization nor does it diminish the importance of managerial competence in marketing divisions of business firms (Marketing Staff of the Ohio State University, 1965). Although there is unanimous agreement which states that marketing as a general theory, but from a variety of criteria have met the requirements, such as expressed by Bahm (1980), Hunt $(1976,1991)$. In accordance with arable fields in the philosophy of science that includes ontology, epistemology and axiology, the science of marketing is also born out of philosophy, which will not be separated from the arable fields. Therefore, this article will review the existence of aspect of marketing theory from Ontology, Epistemology and Axiology aspects.

Ontology Aspects of Marketing: The objects of philosophy of science include the formal object and material one. Formal object is the essence of science, meaning that the philosophy of science concerned with the fundamental problem of science, such as what is the real substance of science? How do I get a scientific truth? In addition, what are the functions of that science to humans (Surajiyo, 2008)? These problems will be 
discussed in this paper. The discussion will begin with aspects of the ontology (what is substance of marketing knowledge really is?). In essence, marketing is a process of exchange between two or more parties (Bagozzi, 1975, 1978). The American Marketing Association define marketing as the activity, set of institution, and processes for creating, communicating, delivering, and exchanging offerings that have value for customers, clients, partners, and society at large (Kotler and Keller, 2012). The similar thing was said by Hunt (1991), the marketing knowledge is a behavioral science that attempts to explain relational exchanges. The next question will be what is needed and who is involved in the exchange? It is according to Kotler and Keller (2012), that what can be exchanged in marketing covering goods, services, events, experiences, people, places, properties, organization, information and ideas. In the meantime, the parties involved in the marketing may be in the form of business sector (business customers and end consumers), as well as nonbusiness sector (private nonprofit institution, government, and individuals), and even global sector (global markets). Moorman and Rust (1999) have conducted research on managers, and have a finding that the marketing function has a key role in managing some of the important relationship between the customer and the critical elements of the company, including customer relationship with (1) product; (2) delivery of services; and (3) financial accountability.

Marketing is not static, but dynamic. This suggests a paradigm shift in marketing practices, even for the time being Kotler and Keller (2012) call it as a holistic marketing concept, which includes aspects of relationship marketing, integrated marketing, internal marketing, and performance marketing. Relationship marketing is as a component in a holistic marketing that looks quite prominent. This concept started much discussed in scientific journals in the 1980s. It could be said that the definitions of the earliest relationship marketing is presented by Berry (1983) in Morgan and Hunt (1994), which defines relationship marketing as a strategy to attract, maintain, and strengthen relationships with customers. Meanwhile, Zeithaml and Bitner (2003) defines relationship marketing as a relationship-based marketing program with viewing from the customer's perspective, by providing better service and attention to customers. More clearly, the substance of marketing appears in Kotler's explanation (1972) in Hunt (1991): The Three Dichotomies Model of Marketing, classifying a marketing phenomenon based on concepts of macro/micro, normative/positive, and the profit sector/nonprofit sector. From this model, it seems the range of marketing is so vast and complete.

In the operationalization of organizations, both for profit organizations and nonprofit organizations, requires the concept of marketing. Kotler and Levy (1969) explained that marketing is not only a function of the business --marketing is a function which is valid for nonprofit organizations as well-- and that the entire organization has a marketing problem that all need to understand marketing. Implementation of the marketing concept in the nonprofit organization called social marketing. Social marketing focuses on the application of knowledge, concepts, and marketing techniques to increase the ultimate goal of social and economic aspects of the form. It also focuses on the analysis of the social consequences of policies, decisions, and marketing activities (Lazer and Kelly, 1973 in Hastings and Saren, 2003). The relationship between social marketing and some conventional marketing can be analogous to the relationship between the game of football and rugby. The two games have in common and the need for a common practice, but each game type has a number of rules, restrictions, and special skills. Good player in the game, the game may not be needed for another (Bloom and Novelli, 1981 in Andreasen, 2002). Thus, we can conclude that from the aspect of ontology, it seems that the substance of marketing is a useful science and mutually beneficial for both the marketer and the stakeholders, or in other words that marketing knowledge is useful knowledge for the benefit of humankind, which can be realized through the exchange process.

Epistemological Aspect of Marketing: According to Bahm (1980), that if something is considered as science when it involved at least six components, among others: problems, attitude, method, activity, conclusion and effects. Meanwhile, according to Buzzell (1963) in Hunt (1991) and in Dharmmesta (2006), that science is: (1) body of knowledge which is classified and systemized; (2) organized around one or several core theories and a number of general principles; (3) is usually expressed in quantitative terms; and (4) knowledge that allows for predictions, and, within certain limits, allows for control over events in the future. Hunt (1976) also revealed that from a positive dimension (for the purpose of explanation, prediction and understanding), then marketing has qualified as a science. Base on these criteria, it can be said that marketing has met the criteria to be called a science. Associated with science, then it will never be separated from the philosophy of science. The second arable area of philosophy is epistemology, which discussed the origins, sources, methods, 
structure and validation or truth of knowledge. In terms of science, epistemology base questions how is the process that allows gaining knowledge in form of science. How is the procedure? What things are to watch out so that we can obtain true knowledge? What is so-called as the truth itself? What are the criteria? What ways, techniques, or means can help us in gaining knowledge in form of science (Suriasumantri, 1993)?

Meanwhile, Siswomihardjo (Lecturer Team of Philosophy of Science in the Faculty of Philosophy UGM, 2007) argued that the epistemology includes the source, facilities, and procedures for using such means to attain (scientific) knowledge. Mind (verstand), experience of ingenuity (vernunft), or a combination of mind and experience, intuition, are the means referred to in epistemology, also known as epistemology models such as rationalism, empiricism, criticism or critical rationalism, positivism, phenomenology with its variations. In the development of social sciences, there are several paradigms, including The Functionalist (positivist) Paradigm, The Interpretive Paradigm, and The Critical Paradigm (Gioia and Pitre, 1990; Sarantakos, 1993). Similarly, in marketing science, Hunt (1991) also revealed there are a number of streams, among others: empiricism, rationalism, idealism, positivism, realism, relativism, and post-relativism, whereas Arndt (1985) wrote the relationship among the orientations, paradigms, metaphors and puzzle solving.

\section{Paradigms in the Science of Marketing}

In his article, Arndt (1985) defines the orientation as the perspective of researchers associated with the role of data, theories and values. Based on the role of researchers and research purposes, it can be identified three marketing orientations, namely empiricism, criticism, and constructivism, while the paradigm is an alternate reality or worldview. Arndt offers four paradigms of marketing, namely the logical paradigm eempiricist, sociopolitical paradigm, a paradigm subjective worldview, and liberating paradigm. The next will be the metaphor becoming the basis for a school of thought. Finally, puzzlele solving is the basis of specific tool and procedure. Most of the marketing experts are strongly influenced by non-marketing disciplines, such as economics, social psychology, sociology, statistics, or mathematics (Hunt, 2001), although there is still debate over the competing three philosophical "isms", namely: logical empiricism, realums scientific, and historical ("Kuhnian") relativism. Hunt (1991) describes a number of ism, among others: empiricism, rationalism, idealism, positivism, realism, and relativism and post-relativism.

Empiricism: The genre of empiricism was originated in the United Kingdom. The genre of empiricism was born as a reaction against the rationalist philosopher who considers less important sensory experience as a source of knowledge. It is according to the genre of empiricism, knowledge of the world can only come to man through the senses. Ingenuity or the ratio does play a role in reviewing and organizing the data, draw conclusions and relate it to other things, but the original source of knowledge remains a sensory experience. The supporters of the genre of empiricism, among others: Sir Francis Bacon, John Locke, David Hume and John Stuart Mill (Hunt, 1991). Logical empiricism is characterized by an inductive statistical method. Following Kuhn and Popper, Laudan argued that the goal of science is to solve the problem. On this view, "truth" or "falsification" of a theory is not relevant as the assessment criteria (Anderson, 1983). Proponents of empiricism (classical empiricism) stated that the development of science always starts from the observation and then inductively generalization is made into a theory or law. The word "classic" in the classical empiricism means that the proponents of this empiricism are strictly and completely use the adage "Experience and observation is the basic source and the main foundation of human knowledge to the world" (Hunt, 1991).

Rationalism: The supporter or proponents of the genre of classical rationalism, among others: Rene Descartes, Benedict de Spinoza and Gottfried Wilhelm Leibniz. The main adage of the genre of rationalism is "a priori reason is the prime foundation of human knowledge to the world." This ism/school bases itself on the belief that people knowledge of the world can be obtained through the use of logic/reason and that sensory input is unreliable. Both rationalism and empiricism became opponents of scholastic learning methods in the development of science. The opposition of empiricism against scholastic is based on the lack of empirical foundation in the development of science, while the opposition of rationalism is by reason of the absence of law or the main principles in the scholastic (Hunt, 1991).

Idealism: Idealism is the approach in philosophy, which stated that the existence of the outside world is not free from the way we view the world. Idealism is often also referred to as "mind-body problem". If 
materialism argues that only material objects that show the reality, the idealism argues that reality appears to the idea existing in the human perception. View of idealism has its roots in the view once expressed by Plato. In terms of Platonian, the idea does not depend on human perception. Proponents of this genre include George Berkeley, Immanuel Kant, and Hegel (Hunt, 1991). German idealism philosophy dominated the thinking of Western philosophy until the early 20th century. The development of German philosophy was initiated by Kant. In the meantime, Hegel triggers absolute idealism. Both philosophers then affect other philosophers. Marx took the vocabulary and idealist values of the Hegel's philosophy. The influence of German philosophy is vast, ranging from the adherents of metaphysical, non-religious institutions, right-wing movement to the left-wing movement. German philosophy, especially Hegel's philosophy is deemed capable of answering the big issues (Hunt, 1991).

Positivism: In France, it emerged social positivism movement (aims to promoting the application of knowledge resulting from scientific methods into the life of the community) at the beginning of the $19^{\text {th }}$ century. The movement is pioneered by the Saint Simont inspired by the philosopher August Comte. According to Comte, the history of the law relates to the stages of thought. Science walks in the path of stages. The stages consist of the theological, metaphysical and positivism ones. Since the 1920s, positivism emerged as a philosophy of science, which is full-fledged in the form of logical positivism. Logical positivism was developed by the Vienna Circle (Anderson, 1983). The supporters of the positivism genre among others: August Comte, Ernst Mach, Gottlob Frege (Hunt, 1991).

Realism: Hunt (2001) revealed that classical realism is one of the four basic principles of modern philosophy of science (the other three are fallibilistic realism, critical realism, and inductive realism) which refers to "scientific realism." After succeeding in the 1960s, relativism, constructivism construction, and irrationalism of Kuhn and Feyerabend, the philosophy of science in the 1970s shifted to realism on the pretext of pursuing the truth back to the philosophy of knowledge. The main problem for realism is that there are so many different versions. Scientific realism is also known as critical realism, which assumes that the task of science is to use a method to improve our process of perception (measurement), illusion separates from reality, and thus produce the most accurate description possibility in comprehending the world (Hunt, 1990). Scientific realism has the following implications: (1) some part of the scientific task would be irrational and not thoroughly if not viewed from the realist perspective; (2) realism guarantees for scientists to work in a category of research activity; (3) numerous oppositions to scientific realism seem to lead to scientific realism, incoherent and misdirected caricature; (4) scientific realism uses some sort of middle ground between the various philosophical systems (Hunt, 1991). The theory can be successful through various means, one of which is the inductive realism that has focused attention on the explanatory, predictive, and the success of the pragmatic theory. Research programs in the field of marketing are consistent with scientific realism, i.e. cognitive theories in consumer behavior, theory of power and conflict in channels of distribution, and portfolio theory in product management (Hunt, 1990).

Relativism and Post-relativism: Relativism views are very influential in the decade of the '60s, especially when the time came great ideas, such as Thomas Kuhn and Paul Feyerabend. Kuhnian relativism dominated the thinking of the philosophy of science at that time. Since the decade of the '60s, a philosophical perspective is known as a historical relativism that has a different premise: (1) historical relativism aims to establish a common scientific theory; (2) an analysis of the historical development of science can be developed to find and justify the knowledge (Hunt, 1991). There are three types of relativism that influence the marketing, i.e: rationality relativism, reality relativism, and the conceptual framework of relativism. Anderson was the one who carried relativism in marketing. Anderson brought the concept of critical relativismm. According to the relativistic Anderson, it seems to be the only solution to the problem of scientific method (Anderson, 1983).

\section{The dominant paradigm in the Science of Marketing}

According to Sarantakos (1993), the paradigm of functionalist/positivist is still dominating in social science research. However, according to Hunt (1991) although various paradigms (empiricism, rationalism, idealism, positivism, realism, Relativism, and post-Relativism) have helped to color the marketing presence, the reality in marketing there is no dominant paradigm, each has its own portion. To support his statement, Hunt bases on research findings of Sheth, Gardner, and Garrett that evaluate the twelve schools of thought, and by 
examining the individual research programs in marketing and identifying characteristics of the underlying (logical positivism and logical empiricism), which concluded there is no dominant philosophy in marketing. Hunt (2001) discusses the dominance of the philosophy in marketing, as in the following descriptions: whether positivism dominates marketing and other social sciences? Philosophical debate answers yes to this question, which is then often followed by argument "positivism is dead": (1) positivist research dominates marketing and social science research; (2) the positivist research reifies could not be observed and quantitative, deterministic, the search for causality realist, functionalist, and/or objectivist; (3) positivism has been proven to die (or completely discredited) in the philosophy of science; (4) all the research which is quantitative, deterministic, causality seeking, and so on is also discredited; (5) therefore, researchers must adopt some forms of relativism qualitative methodology.

Hunt (2001) confirmed the presence of errors on the statement that positivism is the dominant philosophy, is caused by an error of the premise in assuming that marketing science and social science are dominated by positivism. This is in line with the opinion of Anderson (1983) who argued that it seems unlikely that a single perspective would assert its dominance. Authors hope that in the future the development of marketing knowledge can be done at the level of meta-paradigm, which means that marketing researchers are not only focused on one paradigm, but they can be combined from various existing paradigms, so they can deliver better outcome and more beneficial for the development of science and for the benefit of mankind.

Axiology Aspect of Marketing: Axiology is the third of the arable fields of philosophy, which studying values in general, which questioning what is knowledge in form of science for? How is the relation between how-touse and the moral rules? How to determine which objects are reviewed based on moral choices? What about the relation between technical, procedural, which is the operational of the scientific method and moral norms or professional (Suriasumantri, 1985)? Meanwhile, Siswomihardjo (Lecturer Team of Philosophy of Science in the Faculty of Philosophy UGM, 2007) explains that the axiology including values that are normative in giving meaning to the truth. Siswomiharjo also explained that ethics implies that science is applied to enhance human dignity. Not the man is modified by the science, but on the contrary. The nature of ethics requires the application of the science in a responsible manner. Ethics is a critical and fundamental thinking about the teachings and moral views. Ethics comes from the Greek word - ethos which means customs or habits (Keraf, 1998). Ethics is useful for directing people behavior towards goodness and benefits of life. Without ethics, the occurrence is that people will justify any means to get the benefits even may be harmful to others (Hill and Fout, 2005). Ethics is closely related to many-value problems because ethics principally discuss the issues of "moral" and "immoral", "good" and "bad", "true" and "wrong" value predicates. A similar definition is also proposed by Bartels (1967) and Malhotra and Miller (1998).

\section{Ethics in Marketing}

Many authors of articles on marketing ethics who using different normative theories such as deontology, utilitarianism or teleological approach, and morality ethics (e.g., Ferrell and Gresham, 1985; Hunt and Vitell, 1986). Likewise, Malhotra and Miller (1998) use the theory of ethical relativism, justice, objectivism, teleology, deontology, and two hybrid theories (Malhotra and Miller, 1996). But Robin and Reidenbach (1993), argued that although moral philosophy can reasonably be expected to assist in developing a philosophy of marketing ethics, but in fact the marketing needs to develop his own philosophy, so Reidenbach and Robin (1991) developed three characteristics which are useful for the development of workable ethical philosophy to marketing, namely (1) moral relativism; (2) bounded relativism; and (3) descriptive ethics. Reidenbach and Robin (1991) conducted adaptation of the structure proposed by Arndt. Basically, the theoretical perspectives lead to a certain paradigm, which in turn produce a variety of metaphors to describe and visualize an area of core material (Arndt's "puzzle solving"). Reidenbach and Robin see the influence of empirical theoretical perspective in the form of empirics to marketing ethics, the influence of micro-economic paradigm / marketing management to marketing ethics, and logical empirical relationships based on marketing metaphor with marketing ethics. The findings indicate that there is no reason why marketing must pursue this logical marketing metaphor exclusively. The metaphor must contain the social ethics and the human need for a belief which is based on justice and fair treatment of all the marketing environment and must have the ability to integrate these elements together with the need for productivity and profitability. 
Meanwhile, Bartels (1967) suggested that marketing ethics are part of public ethics in business, therefore Bartels tried to build a model for ethical marketing. This model suggests an effort to explain the nature and behavior of some phenomena, for indicating the causes and influences of related variables. The model contains the following elements: (1) ethics as a standard of truth in the behavior; (2) social interaction as an area in which ethical judgment is made; (3) non-economic and economic institutions influence personal behavior through participatory role; (4) expectations on the role to form ethical choices through social sanctions; and (5) social sanctions, rather than technical terms, as a basis for ethical judgments. Another point of view, related to the ethics of marketing, was presented by Brinkmann (2002), in his article it revealed that marketing ethics served as an umbrella for advertising ethics, public relation ethics and the ethics of sales and as an example of professional ethics. In this article, it distinguishes four approaches to professional ethics, namely (1) moral conflict approach; (2) professional code approach; (3) the role of professional morality; and (4) moral climate approach. Brinkmann (2002) also explains that the marketing ethics test marketing systematically and marketing morality is associated with 4P marketing problems such as product security, pricing fraud, deceptive advertising or discrimination in the distribution, and other issues relating to the exploitation of the consumer weakness is by using public relations.

Ethics in Marketing Research: In marketing research, ethical issues derived from the relationship between the researcher with the parties involved in the research process, including the respondents, the research institution clients, research department client (such as in the case of large organizations), and the public. Each party has a duty and responsibility. For example, a researcher has a responsibility to treat the respondent with being honest with them about the nature or purpose of the research study. At the same time, he/she has a responsibility to collect accurate data to his/her clients (Akaah and Riordan, 1989). So far the fulfillment of responsibilities generates many conflicts, namely the raising of ethical issues of research. For example, in an effort to meet the needs of the client's data is accurate and reliable, a researcher may be less honest with respondents about the purpose of the study. Thus, the issue of ethics in marketing research revolves around the balancing between the duties and responsibilities of researchers with the parties involved in the study (Hunt, Chonko, and Wilcox, 1984). Although the American Marketing Association (AMA) has granted marketing research code of conduct, which focuses on the relationship between researcher and client, this code seems most significant to the survey research techniques. Meanwhile, by marketing research with experiments techniques started to be performed a lot. This encourages Tybout and Zaltman (1974) to conduct this study. Another reason is the use of experiments in raising ethical issues in the previous marketing more relevant to psychologists, sociologists, and anthropologists. It is also based on the condition of the developing quantity of marketing research, the ethical issues encountered with greater frequency. Therefore, an understanding of the ethical issues involved in marketing research is very important to produce quality research.

The issues raised in Tybout and Zaltman article (1974) are related to voting right (the subject has the freedom to choose whether they will participate), the right for safety (respondent has the right for safety or freedom from psychology and physic), and the right to be notified (The subjects of research have a right to be notified about all aspects of the study). In a global perspective, Rallapalli (1999) provides a paradigm for evaluating the factors that influence the development of global marketing code of conduct (code of conduct which can be universally accepted around the world), as the results obtained two-level global code of ethics, the normative guidelines and specific behavior. These factors are moderated by moral reasons, organizational ethical climate, the level of economic development, and cultural dimensions. Confidence is essential in science, because scientific knowledge is a form of equitable distribution of knowledge to the client (Hunt 1990, 1991). The importance of trust in marketing theory and marketing research also has ethical implications. The research findings indicate that the problems of the ethical difficulties encountered by marketing researchers in the form of an error in interpreting the research findings (Hunt, 1990). Scientific realism also affects trust and ethics in marketing and marketing research (Hunt, 1991). Rom Harre has been at the forefront among the philosophers who advocated the importance of "moral order" in science. Harre shows that trust plays an important role in all communities. Therefore, the scientists in their role as researchers produce "trustworthy belief" required by their peers and the common community (society) to maintain the moral order (Hunt, 1991). 
Research on the ethics of marketing research with the subjects are marketing professionals (researchers and executives) have been carried out by Akaah and Riordan (1989). Basically the research conducted Akaah and Riordan is intended to compare their findings with a study conducted by Crawford (1970). The findings obtained from this research is the apparent shift in the perception of marketing professionals (researchers and executives) about the variables that have previously been investigated by Crawford. To study the ethical issues (use of hidden recording devices to record interviews, using one-way mirrors to collect data, and use of fictitious company name as a sponsor of research), then the marketing professionals (both executive and researchers) revealed the presence of a stronger disapproval compared with the observation conducted by Crawford. To use ultraviolet ink to precode questioner, marketing researchers show a stronger agreement compared with Crawford's findings. A shift in views on the ethics of this study, it is presumably due to the increase of society attention on business ethics and also the changes in technology research/practice, including the development of data collection and analysis techniques which are increasingly sophisticated (Akaah and Riordan, 1989).

\section{Conclusion}

From the aspect of the ontology, it looks so great benefit and importance of marketing for the welfare of mankind. Although until now marketing has not been admitted as a general theory, but from a variety of characteristics it seems that marketing has been worthy to be called a theory, therefore, from the aspect of epistemology, marketing will not be released from various paradigms of philosophy of science, among others: empiricism, rationalism, idealism, positivism, realism, and relativism and post-relativism. However, the most interesting is that it is none of the paradigms which dominate marketing. Meanwhile, from the aspect of axiology, related to how marketing can be implemented properly, then this will be very closely related with ethical issues. Marketing ethics and ethics in marketing research is a crucial matter, including in this case is trust. However, it seems that these days not many researchers are interested in the topic of ethics in marketing and ethics in marketing research. According Akaah and Riordan (1989), that technological advance factor is related to marketing ethics, therefore the author recommend to do research on this topic, concerning that the technology (especially communications) is progressing very rapidly and business competition are increasingly keen in two last decade.

\section{References}

Akaah, I. P. \& Riordan, E. A. (1989). Judgments of Marketing Professionals about Ethical Issues in Marketing Research: A Replication and Extension. Journal of Marketing Research, 26(1), 112-112.

Anderson, P. F. (1983). Marketing, Scientific Progress, and Scientific Method. The Journal of Marketing, 47(4), 18-31.

Andreasen, A. R. (2002). Marketing Social Marketing in the Social Change Marketplace. Journal of Public Policy \& Marketing, 21(1), 2-13.

Arndt, J. (1985). On Making Marketing Science More Scientific: Role of Orientations, Paradigms, Metaphors, and Puzzle Solving. Journal of Marketing, 49, 11-23.

Bagozzi, R. P. (1975). Marketing as Exchange. The Journal of Marketing, 39(4), 32-39.

Bagozzi, R. P. (1978). Marketing as Exchange: A Theory of Transactions in the Marketplace. American Behavioral Scientist, 21, 535-556.

Bahm, A. J. (1980). What is Science. New Mexico: World Books, Alburquerge.

Bartels, R. (1967). A Model for Ethics in Marketing. The Journal of Marketing, 31(1), 20-26.

Brinkmann, J. (2002). Business and Marketing Ethics as Professional Ethics. Concepts, Approaches and Typologies. Journal of Business Ethics, 41(1/2), 159-177.

Crawford, M. C. (1970). Attitudes of Marketing Executives toward Ethics in Marketing Research. Journal of Marketing, 34, 46-52.

Dharmmesta, B. S. (2006). Teori Pemasaran: Perkembangan Historis Dan Isu-isu Kritis. Makalah tidak dipublikasikan untuk Modul Perkuliahan Program S3 Manajemen (Maret).

Ferrell, O. C. \& Gresham, L. G. (1985). A Contingency Framework for Understanding Ethical Decision Making in Marketing. Journal of Marketing, 49, 87-96.

Gioia, D. A. \& Pitre, E. (1990). Multiparadigm Perspectives on the Theory Building. Academy of Management Review, 15(14), 584-602. 
Gronross, C. (1994). From Marketing Mix to Relationship Marketing: Toward A Paradigm Shift in Marketing. Management Decision, 32(2), 4-20.

Hasting, G. \& Saren, M. (2003). The Critical Contribution of Social Marketing. Theory and Application Marketing Theory, 3(3), 305-322.

Hill, R. B. \& Fout, S. (2005). Work Ethic and Employment Status: A Study of Job Seekers. Journal of Industrial Teacher Education, 42(3), 48-65.

Hunt, S. D. (1976). The Nature and Scope of Marketing. Journal of Marketing, 40, 17-28.

Hunt, S. D. (1990). Truth in Marketing Theory and Research. The Journal of Marketing, 54(3), 1-15.

Hunt, S. D. (1991). Modern Marketing Theory: Critical Issues in the Philosophy of Marketing Science, Cincinnati, OH: South-Western Publishing Co.

Hunt, S. D. (2001). The Influence of Philosophy, Philosophies, and Philosophers on a Marketer's Scholarship. The Journal of Marketing, 65(4), 117-122.

Hunt, S. D., Chonko, L. B. \& Wilcox, J. B. (1984). Ethical Problems of Marketing Researchers. Journal of Marketing Research, 21, 309-324.

Hunt, S. D. \& Vitell, S. (1986). A General Theory of Marketing Ethics. Journal of Macromarketing, 6, 5- 15.

Keraf, S. (1998). Etika Bisnis, Tuntutan dan Relevansinya. Yogyakarta: Kanisius.

Kotler, P. \& Keller, K. L. (2012). Marketing Management. 14th ed., Edinburgh Gate, Essex: Prentice Hall

Kotler, P. \& Levy, S. J. (1969). Broadening the Concept of Marketing. Journal of Marketing, 33, 10-15.

Malhotra, N. K. \& Miller, G. (1996). Ethical Issues in Marketing Managed Health Care. Journal of Health Care Marketing, 16(1), 60-65.

Malhotra, N. K. \& Miller, G. L. (1998). An Integrated Model for Ethical Decisions in Marketing Research. Journal of Business Ethics, 17(3), 263-280.

Marketing Staff of the Ohio State University. (1965). A Statement of Marketing Philosophy. Journal of Marketing, 29 (1), 43-44,

Moorman, C. \& Rust, R. T. (1999). The Role of Marketing. The Journal of Marketing, 63, 180-197.

Morgan, R. M. \& Hunt, S. D. (1994). The Commitment-Trust Theory of Relationship Marketing. Journal of Marketing, 58, 20-38.

Rallapalli, K. C. (1999). A Paradigm for Development and Promulgation of a Global Code of Marketing Ethics. Journal of Business Ethics, 18 (1), 125-137.

Reidenbach, R. E. \& Robin, D. P. (1991). Epistemological Structures in Marketing: Paradigms, Metaphors, and Marketing Ethics. Business Ethics Quarterly, 1(2), 185-200.

Robin, D. P. \& Reidenbach, R. E. (1993). Searching for a Place to Stand: Toward a Workable Ethical Philosophy for Marketing. Journal of Public Policy \& Marketing, 12(1), 97-105.

Sarantakos, S. (1993). Social Research, Melbourne: Mcmillan education, Australia Pty., Ltd.

Shaw, E. H. (2009). Exploration and Insights, Reflections on The History of Marketing Thought. Journal of Historical Research in Marketing, 1 (2), 330-345.

Surajiyo. (2008). Filsafat Ilmu dan Perkembangannya di Indonesia, Yogyakarta: Bumi Aksara.

Suriasumantri, J. S. (1993). Filsafat Ilmu Sebagai Pengantar Populer. Jakarta: Sinar Harapan.

Lecturer Team of Philosophy of Science in the Faculty of Philosophy UGM. (2007). Filsafat Ilmu, Sebagai Dasar Pengembangan Ilmu Pengetahuan. Yogyakarta: Liberty.

Tybout, A. M. \& Zaltman, G. (1974). Ethics in Marketing Research: Their Practical Relevance. Journal of Marketing Research, 11(4), 357-368.

Zeithaml, V. A. \& Bitner, M. J. (2003). Services Marketing: Integrating Customer Focus across The Firm. New York: McGraw-Hill. 